\title{
Student Character Building through Mentoring Activities at SMP Negeri 1 Solok Selatan
}

\author{
Yulinda Etfita ${ }^{1)}$, Maria Montessori ${ }^{2)}$ \\ Pancasila and Citizenship Education Study programs, Faculty of Social Science Universitas Negeri \\ Padang, Prof. Hamka Street, Air Tawar Padang, Indonesia ${ }^{1,2)}$ \\ yulinda17@gmail.com
}

\begin{abstract}
This article aims to describe the implementation of the character building program through mentoring activities at SMP Negeri 1 Solok Selatan. This article uses a qualitative descriptive approach with the research subjects consisting of the vice principal of student affairs, mentoring coaches, mentoring administrators, mentors, and mentoring participants. The results of this study indicate that: 1) The mentoring program at SMP Negeri 1 Solok Selatan is carried out with two activities, namely the main activity which is routine every Saturday, and complementary activities for mentoring participants, mentors, and the mentoring management team;2) There are seven basic character forms produced after participating in mentoring activities at SMP Negeri 1 Solok Selatan. First, increasing the correct understanding of Islam according to the Al Quran and Sunnah. Second, the close brotherhood between mentoring students. Third, the students' ability to advise each other. Fourth, increasing student achievement in the religious, academic and non-academic fields. Fifth, the implementation of congregational worship at the mosque. Sixth, the improvement of students' abilities in reading the $\mathrm{Al}$ Quran. Seventh, the realization of good interactions between students and teachers, students and staff, and students and students.
\end{abstract}

Keywords: Character Development; Mentoring Activities; Descriptive Research

\begin{abstract}
Abstrak. Artikel ini bertujuan untuk mendeskripsikan pelaksanaan program pembinaan karakter melalui kegiatan mentoring di SMP Negeri 1 Solok Selatan. Artikel ini menggunakan pendekatan deskriptif kualitatif dengan subjek penelitian terdiri dari wakil kepala sekolah bagian kesiswaan, pembina mentoring, pengurus mentoring, mentor, dan peserta mentoring. Hasil penelitian ini menunjukkan bahwa: 1) Pelaksanaan program mentoring di SMP Negeri 1 Solok Selatan dilaksanakan dengan dua kegiatan yakni kegiatan utama yang secara rutin setiap hari Sabtu, dan kegiatan pelengkap untuk peserta mentoring, mentor, dan tim pengelola mentoring; 2) Terdapat tujuh bentuk karakter dasar yang dihasilkan setelah mengikuti kegiatan mentoring di SMP Negeri 1 Solok Selatan. Pertama, bertambahnya pemahaman Islam yang benar sesuai dengan Al Quran dan Sunnah. Kedua, eratnya persaudaraan antar siswa mentoring. Ketiga, kemampuan siswa dalam saling menasehati. Keempat, meningkatnya prestasi siswa baik bidang keagamaan, akademik, maupun non akademik. Kelima, pelaksanaan ibadah secara berjamaah di masjid. Keenam, peningkatan kemampuan siswa dalam membaca Al Quran. Ketujuh, terwujudnya interaksi yang baik antara siswa dengan guru, siswa dengan staf, dan siswa dengan siswa.
\end{abstract}

Kata Kunci: Pembinaan Karakter, Siswa, Mentoring 


\section{INTRODUCTION}

The mentoring activity is one of the coaching activities that have the power to pierce the heart, stimulate the mind, and awaken the soul with the learning method in a circular sitting position guided by a mentor with a number of members ranging from ten to fifteen people. The mentoring activity that the author means here is the activity of fostering religious values with full inspiration and intimacy between mentors and mentees in an effort to improve religious attitudes in everyday life. Furthermore, a religious attitude is a condition that exists within a person that encourages someone to behave in accordance with the level of obedience to religion. This religious attitude creates consistency in religion as an effective element and behavior towards religion as a guide for life.

Mentoring activities in SMP are carried out by means of character development through Small Group Guidance Activities. Small-Group Guidance Activities are individual services in groups provided by schools to students, in order to develop character and foster student potential in a tawazun / balanced manner between spiritual potential (heart and feeling), intellect potential, and physical potential through routine programs and evaluations. weekly and relationships based on love and affection, development of character values such as giving attention, exemplary, straightening understanding, mentoring, motivation and evaluation, guidance for worship, caring and cultivating which will create character junior high school students.

The basis for the mentoring activity chosen as a form of Character Building at SMP Negeri 1 Solok Selatan is found in the educational theory which states that the learning process will be effective if the maximum number of students is fifteen people. In this way, the teacher will be more focused and maximal in guiding, accompanying, and serving students. In addition, all students will also get adequate attention and service from the teacher (Individual service). This teaching and learning process will also increase the active involvement of students in the class, especially in mentoring activities.

Small group guidance is a guidance technique that can help individuals develop optimally according to their abilities, talents, interests, and values which are carried out in groups. Group guidance aims to prevent problems from arising in students and develop their potential. Seeing the situation of the younger generation lately and with the discourse of character order in the national personality, various variations of character education have emerged. The formulation of character education is useful for forming a nation that is strong, characterized, dignified, and respected in the international world. To get such a nation and state, it is necessary to apply the correct character education. In Indonesia 
itself, character education has long been echoed in the world of education. Given the importance of character education for the nation's children, this study raises one of the most basic, fundamental, and effective characters to control behaviour and shape good student character, namely religious character. This religious character education has been implemented by many schools in the form of full-day school programs, boarding schools, and religious-based schools. SMP Negeri 1 Solok Selatan is one of the first schools to implement character education in South Solok and is also active in instilling religious character in students. Based on the results of observations, one of the problems in SMP Negeri 1 Solok Selatan is the implementation of character values in students that are not in accordance with the expected implementation. One of the strategies for developing student character that has been carried out at SMP Negeri 1 Solok Selatan is through mentoring activities. Mentoring is the focus of this research because it is not known that mentoring activities are generally at the university or secondary school level while mentoring at the basic education level has not been implemented. Mentoring as a forum for student religious guidance can be more effectively applied from an early age or at the age of Elementary and Junior High Schools. Basically, humans have the potential of good character before humans develop. However, this potential must be continuously fostered through socialization and education from an early age. Therefore, mentoring activities are one of the right solutions as a forum for fostering religious character in students of primary education age.

\section{Mentoring activities at SMP Negeri 1}

Solok Selatan are held every Thursday. This activity is guided by several teachers who have been appointed as mentors. In this activity, there are several aspects including memorizing prayers and hadiths which will be discussed together about the benefits, uses, and relationships with the formation of student character. On Saturdays, mentoring activities have a longer duration than other days. On Monday-Friday, mentoring activities last for thirty minutes, but on Saturday, mentoring activities are held for forty-five minutes or one hour of lessons.

Mentoring activities must be followed by all SMP Negeri 1 Solok Selatan students because the school realizes that the age of junior high school students is psychologically the age at which they are known as adolescence or puberty. At this age, there are many changes and developments experienced by students. This transition period often leaves the individual concerned with confusing situations. On the one hand, children at this age still fall into the category of children. However, on the other hand, they already have to behave like adults. This situation often causes shocks in adolescents who are looking for identity, resulting in various kinds of 
conflicts such as strange behavior which, if not directed properly, will lead to delinquency and fatal social illness. With this in mind, this article will further describe Student Character Development through Mentoring Activities at SMP Negeri 1 Solok Selatan.

\section{RESEARCH METHODS}

This type of research was qualitative research using descriptive type where the researcher described and revealed all phenomena, symptoms, events as they were in the form of information that occurred at the place under study. The qualitative method looked at the phenomenon more broadly and deeply following what happened and developed in the social situation under study, namely the study of the implementation of character building for students at SMP Negeri 1 Solok Selatan through mentoring activities (Sugiyono, 2009). This writing was intended to reveal the character building of students at SMP Negeri 1 Solok Selatan through mentoring activities, in addition to finding the effectiveness of the implementation of character development at SMP Negeri 1 Solok Selatan through mentoring activities and finally to find better efforts in implementing character building in SMP Negeri 1 Solok Selatan through mentoring activities. The informants in this study were determined by purposive sampling. Purposive sampling according to Bungin (2003: 53), namely determining informants with certain considerations who were considered to be able to provide maximum data. Based on the purposive sampling technique, the informants in this study were: Principals and Teachers, student representatives, school supervisors and parents and students of SMP Negeri 1 Solok Selatan.

\section{DISCUSSION}

Mentoring activities carried out at SMP Negeri 1 Solok Selatan as a means of developing student character have been carried out by giving rise to many activities based on Faith and Piety (IMTAQ) and science and technology (IPTEK). These activities, both directly and indirectly, have supported the general character improvement of SMP Negeri 1 Solok Selatan students. The implementation of mentoring activities as a means of developing student character itself is one form of national education as stipulated in Article 3, Law No. 20 of 2003 which states that the function of national education is to develop and shape the character and civilization of the nation with dignity in the context of educating the nation's life. Besides, this mentoring activity has also succeeded in developing the potential of students in strengthening the value of faith and devotion to God Almighty who is noble, healthy, knowledgeable, competent, creative, independent, and becomes democratic and responsible students.

At SMP Negeri 1 Solok Selatan, the mentoring-based character education strategy 
includes two types of activities, namely the main activity and the companion activity. The main mentoring activity which is carried out takes place every Thursday while the companion or additional activities are carried out at certain times. This mentoring activity is one form of adaptation of Islamic mentoring activities that are usually carried out in universities, however, at SMP Negeri 1 Solok Selatan, this mentoring activity is also carried out as an effort to develop the character of students in schools.

Mentoring activities carried out at SMP Negeri 1 Solok Selatan are under the character education strategy put forward by Doni Koesoema (2007) which includes teaching, modelling, determining priorities, practical priorities, and reflection. Mentoring activities at SMP Negeri 1 Solok Selatan require a mentor to be able to teach, be an example, direct, and practice the character values of the students under his guidance. In addition, students are also required to be able to reflect both individually and in groups on problems that arise during the mentoring.

Mentoring activities as a means of character development for students at SMP Negeri 1 Solok Selatan are implemented by carrying out the character approach strategy proposed by Hasan (1985). During the mentoring activities, mentors are trained to always be role models for students by getting used to doing all the positive values of character development. Thus, mentoring participants become self-disciplined.

Cultivating character values for students also requires a conducive situation. So those mentoring activities at SMP Negeri 1 Solok Selatan are always sought to be conducive and comfortable by holding various fun activities such as chanting, watching together, playing games, or eating together. These activities make students as mentoring participants to feel closer and more comfortable with their mentors. This condition will later make students not burdened in following the mentoring process.

Hasan (1985) also stated that habituation is one of the keys in character development. Therefore, mentoring activities at SMP Negeri 1 Solok Selatan are held every week on Thursday so that students become accustomed and disciplined. Besides, outside of mentoring activities, students are also monitored in carrying out daily worship which is part of the mentoring agenda at SMP Negeri 1 Solok Selatan.

The research findings show that the character of students following the mentoring program is carried out as follows:

Table 14. Student Character Results After Following the Mentoring Program

\begin{tabular}{|c|c|c|}
\hline No. & $\begin{array}{c}\text { Expected } \\
\text { Value }\end{array}$ & Behavior \\
\hline 1. & $\begin{array}{l}\text { Increasing } \\
\text { the correct } \\
\text { understandi } \\
\text { ng of Islam } \\
\text { according }\end{array}$ & $\begin{array}{l}\text { a. Students do not do } \\
\text { actions leading to } \\
\text { shirk. } \\
\text { b. Students take the } \\
\text { initiative themselves }\end{array}$ \\
\hline
\end{tabular}




\begin{tabular}{|c|c|c|}
\hline No. & $\begin{array}{c}\text { Expected } \\
\text { Value }\end{array}$ & Behavior \\
\hline & $\begin{array}{l}\text { to } \quad \text { Al- } \\
\text { Quran and } \\
\text { Sunnah }\end{array}$ & $\begin{array}{l}\text { to provide culture in } \\
\text { AMT } \\
\text { (mabit). }\end{array}$ \\
\hline 2. & $\begin{array}{l}\text { Strengtheni } \\
\text { ng the } \\
\text { brotherhoo } \\
\text { d between } \\
\text { mentoring } \\
\text { students }\end{array}$ & $\begin{array}{l}\text { a. Students get along } \\
\text { well with other } \\
\text { students at school } \\
\text { such as family. } \\
\text { b. Students have } \\
\text { emotional bonds with } \\
\text { other students so they } \\
\text { feel homesick to meet } \\
\text { their mentoring group, } \\
\text { even if their } \\
\text { mentoring activities } \\
\text { continue to the next } \\
\text { level }\end{array}$ \\
\hline 3. & $\begin{array}{l}\text { Mentoring } \\
\text { as a means } \\
\text { of } \\
\text { regeneratin } \\
\mathrm{g} \text { Muslim } \\
\text { students to } \\
\text { want to } \\
\text { move to } \\
\text { call for } \\
\text { things that } \\
\text { are good } \\
\text { (good) and } \\
\text { prevent } \\
\text { them from } \\
\text { being evil } \\
\text { (bad) }\end{array}$ & $\begin{array}{l}\text { a. Students give culture } \\
\text { in turn during the } \\
\text { mentoring. } \\
\text { b. Students invite } \\
\text { goodness and prevent } \\
\text { badness which is } \\
\text { accommodated } \\
\text { through the ROHIS } \\
\text { organization. }\end{array}$ \\
\hline 4. & $\begin{array}{l}\text { Improve st } \\
\text { udents' inte } \\
\text { llectuality } \\
\text { in the } \\
\text { religious, } \\
\text { academic } \\
\text { and non- } \\
\text { academic } \\
\text { fields }\end{array}$ & 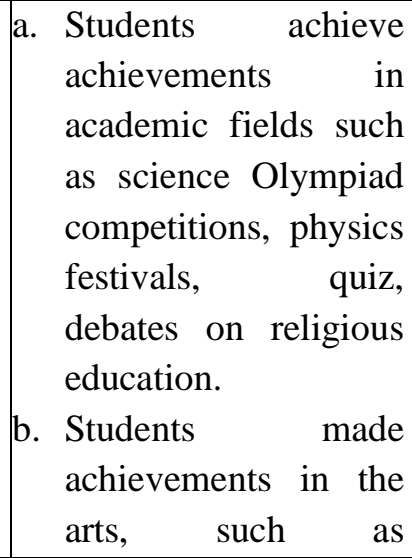 \\
\hline
\end{tabular}

\begin{tabular}{|c|c|c|}
\hline No. & $\begin{array}{c}\text { Expected } \\
\text { Value }\end{array}$ & Behavior \\
\hline & & $\begin{array}{l}\text { musabaqoh qiroatil } \\
\text { pole pesantren, MTQ } \\
\text { at the provincial level }\end{array}$ \\
\hline 5. & $\begin{array}{l}\text { The } \\
\text { number of } \\
\text { students } \\
\text { praying in } \\
\text { congregati } \\
\text { on in } \\
\text { mosques } \\
\text { and } \\
\text { worshippin } \\
\text { g Sunnah } \\
\text { increase }\end{array}$ & $\begin{array}{l}\text { a. The intensity of } \\
\text { students when dzuhur } \\
\text { prayer takes place. } \\
\text { b. Students fill mosques } \\
\text { and halls during } \\
\text { midday prayers. } \\
\text { c. Students perform } \\
\text { dhuha prayers during } \\
\text { recess. } \\
\text { d. Students carry out the } \\
\text { fast Monday } \\
\text { Thursday. }\end{array}$ \\
\hline 6. & $\begin{array}{l}\text { Students' } \\
\text { ability to } \\
\text { read Al } \\
\text { Quran } \\
\text { increases }\end{array}$ & $\begin{array}{l}\text { a. Students read Al- } \\
\text { Quran fluently and } \\
\text { pay attention to the } \\
\text { reading. }\end{array}$ \\
\hline 7. & $\begin{array}{l}\text { Students } \\
\text { who have } \\
\text { good } \\
\text { morals and } \\
\text { respect for } \\
\text { their } \\
\text { parents and } \\
\text { teachers }\end{array}$ & $\begin{array}{l}\text { a. Students interact well } \\
\text { with teachers, } \\
\text { students with staff, } \\
\text { students } \\
\text { students. } \\
\text { b. Students practice } \\
\text { honesty, } \\
\text { responsibility, respect } \\
\text { for others, in dealing } \\
\text { with peers, with older } \\
\text { ones, as well as with } \\
\text { younger ones. }\end{array}$ \\
\hline 8. & $\begin{array}{l}\text { Students } \\
\text { are } \\
\text { personally } \\
\text { able to face } \\
\text { and solve } \\
\text { problems } \\
\text { without }\end{array}$ & $\begin{array}{l}\text { a. Students are able to } \\
\text { solve problems faced } \\
\text { through discussions } \\
\text { that have been carried } \\
\text { out with their mentors } \\
\text { and group friends. }\end{array}$ \\
\hline
\end{tabular}




\begin{tabular}{|c|c|c|}
\hline No. & $\begin{array}{c}\text { Expected } \\
\text { Value }\end{array}$ & Behavior \\
\hline & $\begin{array}{l}\text { causing } \\
\text { disorientati } \\
\text { on }\end{array}$ & 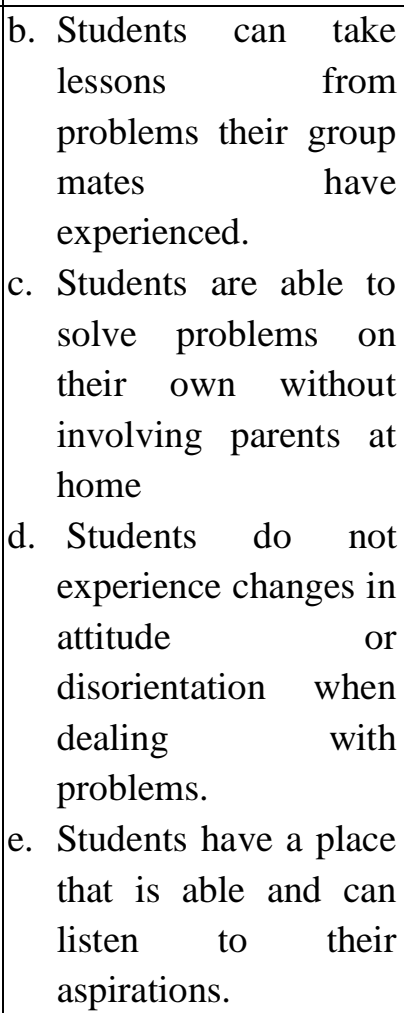 \\
\hline 9. & $\begin{array}{l}\text { Students } \\
\text { have a } \\
\text { desire to } \\
\text { change for } \\
\text { the better }\end{array}$ & $\begin{array}{l}\text { a. Through mentoring, } \\
\text { students will usually } \\
\text { be motivated by their } \\
\text { peers and mentors. } \\
\text { b. Student achievement } \\
\text { increases because of } \\
\text { the motivation to learn } \\
\text { from friends and } \\
\text { mentors. } \\
\text { c. Students become } \\
\text { more motivated to } \\
\text { become devout } \\
\text { Muslims. }\end{array}$ \\
\hline
\end{tabular}

The table above reveals the results of students' character after participating in the mentoring program. This activity is carried out once a week on Thursday by dividing the mentoring participants into small groups totalling 10-15 students. Each group will be accompanied by one or two mentors as the main advisor who will meet for approximately 1-2 hours regularly.

The location of the mentoring is free according to a mutual agreement, it could be in the Musshala, the classroom terrace, the schoolyard or the classroom. The mentoring activity began with the opening of the mentor and continued with reading the Quran in turn from the mentoring participants. The mentoring agenda is then determined by discussing the theme of certain materials or sharing experiences. The material tends to adjust to the curriculum that has been compiled so that it has a sequence and linkages with one another.

The methods used in delivering mentoring materials also vary from one mentor to another. Mentors usually adjust the context of the material to be conveyed to mentor participants. The approach most often used in mentoring at SMP Negeri 1 Solok Selatan is lectures. However, there are also mentors who make games in delivering the material. Other methods used in mentoring are modelling, watching movies, and also attracting sympathy from mentoring participants.

Complementary activities are carried out incidentally according to their needs and desires. At SMP Negeri 1 Solok Selatan, complementary activities were carried out not only for mentoring participants but also for mentoring managers and mentors. Examples of complementary activities that have been 
carried out are the general mentoring stadium, mentor training, joint outings, and others.

The purpose of these activities, both primary and complementary in nature, is to create active and always developing students. This is in line with the mandate of Law Number 20 of 2003 concerning the National Education System regarding the meaning of education, namely to create students who actively develop their potential to have spiritual strength, self-control, personality, intelligence, noble character, and the skills they need., society, nation and state.

\section{CONCLUSION}

The implementation of character building through mentoring activities at SMP Negeri 1 Solok Selatan has succeeded in implying religious values, honesty, tolerance, discipline, hard work, creative, independent, democratic, curious, the spirit of nationalism, love for the country, respect for achievement, communicative, love peace, love reading, care about the environment, care socially, and be responsible in accordance with the character values recommended by the Ministry of National Education. The strategy implemented by the school in facilitating students to implement character values in mentoring activities at SMP Negeri 1 Solok Selatan is to carry out regular mentoring activities every Thursday as the main activity carried out through small groups with several delivery methods such as lectures, exemplary, attract sympathy from mentoring participants, games, watching movies, and discussions

\section{REFERENCES}

[1] Afrizal. (2018). Penelitian Kualitatif. Jakarta: Kencana Prenada Media.

[2] Agboola, A., \& Tsai, K. C. (2012, April). Bring Character Education into Classroom. European Journal of Education Research, l(2).

[3] Alimah, S. (2017). Meta-analysis of learning design on sciences to develop a teacher's professionalism training mode. International Conference on Mathematics, Science and Education $2017 \quad$ (ICMSE2017). IOP Publishing IOP Conf. Series: Journal of Physics.

[4] Amri, S., Jauhari, A., \& Elisah, T. (2011). Implementasi Pendidikan Karakter dalam Pembelajaran (Strategi Analisis dan Pengembangan Karakter dalam Proses Pembelajaran). Jakarta, Indonesia: Prestasi Pustaka.

[5] Agustang, A., \& Sahabuddin, J. (2020, October). MODEL KOLABORASI SOSIAL PENDIDIKAN KARAKTER DI SEKOLAH SWASTA KECAMATAN BISSAPPU KABUPATEN BANTAENG. In PROSIDING SEMINAR DAN DISKUSI PENDIDIKAN DASAR.

[6] Benninga, J. S. (2003). The relationship of Character Education Implementation and Academic Achievment in Elementary School. Journal of Research in Character Education, 1(1), 19-32.

[7] Berkowitz, M. (2007). What Works in Character Education. Journal of Research in Character Education, 5(1), 29-48.

[8] Burhan, B. (2012). Analisis Data Penelitian Kualitatif. Jakarta: Rajawali Press.

[9] Depiyanti, O. M. (2012, September). Model Pendidikan Karakter di Islamic Full Day School. Jurnal Tarbawi, 1(3). 
[10] Dewey, J. (1916). Democracy and Education. United States: macmilan.

[11] Dira, M. (2019). Pendidikan Karakter Melalui Keteladanan Guru Di SDIT Adzkia II Padang. Padang: Universitas Negeri Padang.

[12] Grineski, S. (2003). A University and Community-Based Partnership: After-School Mentoring for Low-Income Youth. ERIC School Community Journal, 13(1), 101-14.

[13] Gunawan, H. (2012). Pendidikan Karakter: Konsep dan Implementasi. Alfabeta.

[14] Hamid, H. (2012). Pendidikan Karakter Perspektif Islam. Bandung: Pustaka Setia.

[15] Hasan, S. H. (1995). Pendidikan Ilmu Sosial. jakarta: Proyek Pendidikan Tenaga Akademik.

[16] Hendriyana, R. (2015). Pengaruh Kegiatan Mentoring Terhadap Akhlak Siswa SMA Negeri 1 Parung. Jakarta: Universitas Islam Negeri Syarif Hidayatullah.

[17] Hidayatullah, F. (2010). Pendidikan Karakter: Membangun Peradaban Bangsa. Surakarta: Yuma Pustaka.

[18] Jalaludin. (2012). Membangun SDM Bangsa Melalui Pendidikan Karakter. Jurnal Penelitian Pendidikan, 13(2).

[19] Kemendiknas. (2010). Pembinaan Pendidikan Karakter di Sekolah Menengah Pertama. Jakarta: Kemendiknas.

[20] Kinkopf, T. W., \& Casey, C. (2016). Character Education: Teachers' Perceptions of its Implementation in the Classroom. Delta Journal of Education, 6(1).

[21] Koesoema, D. (2007). Strategi Mendidik Anak di Zaman Global. Jakarta, Indonesia: Grasindo.

[22] Komosa-Hawkins, K. (2010). Best Practices in School-Based Mentoring Programs for Adolescents. Child \& Youth Services, 31, 131-127.
[23] Kanji, H., Nursalam, N., Nawir, M., \& Suardi, S. (2019). Evaluasi Integrasi Pendidikan Karakter dalam Pembelajaran Ilmu Pengetahuan Sosial di Sekolah Dasar. JED (Journal of Etika Demokrasi), 4(2).

[24] Kanji, H., Nursalam, N., Nawir, M., \& Suardi, S. (2020). INTEGRATION OF SOCIAL CARE CHARACTERS AND MORAL INTEGRATIF ON SOCIAL SCIENCE LESSONS IN ELEMENTARY SCHOOL. AL-ISHLAH: Jurnal Pendidikan, 12(2), 413-427.

[25] Lickona, T. (1991). Educating for Character: How Our School Can Teach Respect and. Responsibility. New York: Bantam Book.

[26] Lockwood, A. T. (1997). Character Education: Controversy and consensus. Thousand Oaks, California, United States: Corwin Press.

[27] Lubis, S. H. (2002). Menjadi Murabbi Sukses. Pustaka Hamasah.

[28] Majid, A., \& Andayani, D. (2012). Pendidikan Karakter Perspektif Islam. Bandung: Remaja Rosda Karya.

[29] Merdekawati, K. (2017). Character Education in Perspective of Chemistry Pre-Service Teacher. AIP Conf. Preceding.

[30] Miles, M. B., \& Huberman, M. (1992). Analisis Data Kualitatif: Buku Sumber Tentang Metode-Metode Baru. Jakarta : Universitas Indonesia. (T. R. Rohidi, Penerj.) Jakarta: Penerbit Universitas Indonesia.

[31] Mislia, Mahmud, A., \& Manda, D. (2016). The Implementation of Character Education through Scout Activities. International Education Studies, 9(6).

[32] Moleong, L. J. (2013). Metodologi Penelitian Kualitatif (Revised ed.). Bandung: Remaja Rosdakarya.

[33] Muhammad, J. (2013). Penguatan Identitas Melalui Mentoring Smada (Studi Kritis Atas Pendidikan Karakter Berbasis Mentoring Di 
Sma Negeri 2 Yogyakarta). National Edication Conference. Bandung: UPI Bandung.

[34] Muscott, H. S., \& O'Brien, S. T. (2016) Teaching Character Education to Students with Behavioral and Learning Disabilities through Mentoring Relationships. International Education Studies, 7(3).

[35] Muslich, M. (2011). Pendidikan Karakter: Menjawab Tantangan Krisis Multidimensional. Jakarta: Bumi Aksara.

[36] Mustari, M. (2014). Nilai Karakter: Refleksi untuk Pendidikan. . RajaGrafindo Persada.

[37] Novitasari, D. (2017). Mentoring Agama Islam Sebagai Alternatif Dalam Pembentukan Karakter siswa. Jurnal Inovasi Pendidikan: Bunga Rampai - Kajian Pendidikan Karakter, Literasi, dan Kompetensi Pendidik dalam Menghadapi Abad 21. Semarang: Universitas Sebelas Maret.

[38] Otten, E. H. (2000). (2000). Character Education. Bloominton, Indiana, United States: ERIC Clearinghouse for Social Studies/Social Science Education Indana University.

[39] Pala, A. (2011). The Need for Character Education. International Journal of Social Sciences and Humanity Studies, 3(2), 23-32.

[40] Pamungkas, M. I. (2017). Penanaman Nilainilai Islam dalam Kegiatan Sebelum Belajar Siswa di SMP PGII 1 Bandung. TA'DIB, 4(1).

[41] Prasetyo, G. (2014). Pelaksanaan Program Mentoring dalam Membentuk. Karakter Peserta didik SMAN 5 Yogyakarta. Journal Student UNY, Journal.student.uny.ac.id.

[42] Prayitno, A. K. (2011). Model pendidikan karakter-cerdas. Padang, Sumatera Barat, Indonesia: UNP Press.

[43] Prayitno, A. K. (2011). Wujud Penghayatan dan Pengamalan Nilai-Nilai Karakter Cerdas. Padang: UNP Press.
[44] Qodratullah, W. (2017). Persepsi Mahasiswa Terhadap Program Pendidikan Karakter melalui Mentoring Pendidikan Agama Islam di Politeknik Negeri Bandung. Jurnal Handayani, 7(1), 13-19.

[45] Rahman, E. N. (2014). Kegiatan Mentoring Keagamaan Islam dan Implikasinya Terhadap Kematangan Beragama Siswa Kelas X SMA Negeri 1 Yogyakarta. Yogyakarta: Universitas Islam Negeri Sunan Kalijaga.

[46] Republik Indonesia. (2005). Undang-undang Nomor 20 Tahun 2003 tentang Sistem Pendidikan Nasional \& Undang-undang No.14 th 2005 tentang Guru \& dosen. Jakarta: VisiMedia.

[47] Romansah, T. (2017). Implementasi Kegiatan Mentoring Keagaman Dalam Pembinaan Karakter Islami. Atthulab: Islamic Religion Teaching and Learning Journal, 2(1).

[48] Ruswandi, M. (2012). Manajemen Mentoring. Karawang: Ilham Publishing.

[49] Suardi, S., Herdiansyah, H., Ramlan, H., \& Mutiara, I. A. (2019). Implementasi Pendidikan Karakter Melalui Mata Pelajaran Pendidikan Kewarganegaraan di SMA Jaya Negara Makassar. JED (Journal of Etika Demokrasi), 4(1).

[50] Suardi, S., Megawati, M., \& Kanji, H. (2018). Pendidikan Karakter di Sekolah (Studi Penyimpangan Siswa di Mts Muhammadiyah Tallo). JED (Journal of Etika Demokrasi), 3(1).

[51] Suardi, S. (2018). Penerapan Model Pembelajaran Saintifik Approacd Berbasis Media Pembelajaran Kearifan Lokal pada Mata Kuliah Dasar-Dasar Sosiologi dalam Membangun Karakter dan Meningkatkan Hasil Belajar Mahasiswa Pendidikan Sosiologi Universitas Muhammadiyah Makassar. JED (Journal of Etika Demokrasi), 3(2).

[52] Safitri. (2011). Manfaat Program Mentor Bagi Siswa Minoritas Di Lingkungan Pendidikan Kajian Jurnal: Mentoring In A PostAffirmative Action World. Jurnal Psikologi, 
9(1). Dipetik $03 \quad 30, \quad 2019$, dari http://digilib.esaunggul.ac.id/public/UEU-

Journal-5014-Safitri\%20.pdf

[53] Sahlan, A. (2012). Desain Pembelajaran Berbasis Pendidikan Karakter. Yogyakarta: Ar-Ruzz Media.

[54] Salahudin, A. (2013). Pendidikan Karakter (Pendidikan Berbasis Agama dan Budaya Bangsa). Bandung: Pustaka Setia.

[55] Salleh, H., \& Tan, C. (2013). Novice Teachers Learning from Others: Mentoring in Shanghai Schools. Volume 38 | Issue. Australian Journal of Teacher Education, 38(3), 152165.

[56] Siregar, I. (2014). Model Pendidikan Karakter Melalui Pendidikan Agama: Kasus di SMAN 3 Medan. Penamas, 28(1), 43-58.

[57] Sulistyowatri, E. E. (2009). Analisis Pelaksanaan Mentoring Dalam Pembentukan Konsep Diri Pelajar SMA Pada Lembaga ILNA Youth Centre Bogor. Jakarta: Universitas Syarif Hidayatulloh.

[58] Suyadi. (2013). Strategi pembelajaran pendidikan Karakter. Bandung, Jawa Barat: Remaja Rosdakarya.

[59] Wibowo, A. (2013). Pendidikan Karakter di Perguruan Tinggi. Yogyakarta: Pustaka Pelajar.

[60] Zubaedi. (2011). Desain Pendidikan Karakter. Jakarta, Indonesia: Kencana. 